\title{
Renal function evaluation in patients with American Cutaneous Leishmaniasis after specific treatment with pentavalent antimonial
}

\author{
Rodrigo A Oliveira ${ }^{*}$, Cláudio G Lima ${ }^{1}$, Rosa M S Mota ${ }^{2}$, Alice M C Martins ${ }^{3}$, Talita R Sanches ${ }^{4}$, Antônio C Seguro ${ }^{4,7}$,
} Lúcia C Andrade ${ }^{4,7}$, Geraldo B Silva Junior ${ }^{5,6}$, Alexandre B Libório ${ }^{6}$ and Elizabeth F Daher ${ }^{5,7}$

\begin{abstract}
Background: Renal evaluation studies are rare in American Cutaneous Leishmaniasis (ACL). The aim of this study is to investigate whether specific treatment reverts $A C L$-associated renal dysfunction.

Methods: A prospective study was conducted with 37 patients with ACL. Urinary concentrating and acidification ability was assessed before and after treatment with pentavalent antimonial.

Results: The patients mean age was $35.6 \pm 12$ years and 19 were male. Before treatment, urinary concentrating defect $\left(U / \mathrm{P}_{\text {osm }}<2.8\right)$ was identified in 27 patients $(77 \%)$ and urinary acidification defect in 17 patients $(46 \%)$. No significant glomerular dysfunction was observed before and after specific ACL treatment. There was no reversion of urinary concentrating defects, being observed in $77 \%$ of the patients before and in $88 \%$ after treatment $(p=0.344)$. Urinary acidification defect was corrected in 9 patients after treatment, reducing its prevalence from $40 \%$ before to only $16 \%$ after treament, $(p=0.012)$. Microalbuminuria higher than $30 \mathrm{mg} / \mathrm{g}$ was found in $35 \%$ of patients before treatment and in only $8 \%$ after treatment. Regarding fractional excretion of sodium, potassium, calcium, phosphorus and magnesium, there was no significant difference between pre and post-treatment period.

Conclusion: As previously described, urinary concentrating and acidification defects were found in an important number of patients with ACL. Present results demonstrate that only some patients recover urinary acidification capacity, while no one returned to normal urinary concentration capacity.
\end{abstract}

Keyword: American cutaneous leishmaniasis, Renal function, Tubular defects, Treatment

\section{Background}

Leishmaniasis is a parasitic disease caused by Leishmania species which could manifest as visceral, mucous or cutaneous involvement, depending on the host immune response [1-4].

It is estimated that 1.5 to 2 million people develop symptomatic disease each year [5]. American Cutaneous Leishmaniasis (ACL) is endemic in some countries in Africa, Middle East, Europe and Latin America, representing a Public Health problem, not only due to its high incidence, but also due to its potential to cause destructive

\footnotetext{
* Correspondence: rodrigoalves@ufc.br

'Department of Internal Medicine, School of Medicine, Federal University of Ceará, Campus Cariri, Rua Divino Salvador, 284, Centro, Barbalha, Ceará, Brazil CEP-63180-000

Full list of author information is available at the end of the article
}

and incapacitating lesions, with high psychosocial impact $[4,6]$.

Renal involvement has been described in visceral leishmaniasis (kala-azar), including from mild urinary abnormalities to severe glomerular involvement and renal failure [7-10]. Renal failure in kala-azar is thought to occur due to interstitial nephritis secondary to immune complex deposition and hypersensitivity to pentavalent antimonials [6,11-13]. Tubular dysfunction has also been described in kala-azar as urinary concentrating and acidification defects, with few clinical manifestations [14].

In ACL there are very few studies regarding renal function evaluation, and the renal abnormalities described are linked to specific treatment with pentavalent antimonials [15]. These drugs are described to cause acute kidney injury due to hypersensitivity reaction [12]. Other

\section{() Biomed Central}


possible mechanisms for kidney injury in ACL have not been investigated by now.

A recent study conducted by our study group found important abnormalities in ACL. Expression of the $\mathrm{Na}$ ${ }^{+} / \mathrm{H}^{+}$exchanger (NHE3), $\mathrm{H}^{+}$-ATPase, and pendrin were all significantly higher in patients with ACL when compared with normal subjects. A combined urinary concentration and acidification defect was found in $32.4 \%$ of patients, before specific ACL treatment [16].

The aim of this study is to investigate if these tubular abnormalities persist after specific ACL-treatment.

\section{Methods}

\section{Patients}

This is a prospective study with 37 patients with confirmed diagnosis of ACL (epidemiologic, clinical and laboratorial) in a public health service in the city of Barbalha, Ceara, Brazil, between July 2008 and July 2009. Exclusion criteria was patients under 15 years-old or older than 60 years, use of pentavalent antimonials in the last 30 days, hypertension (Systolic blood pressure $\geq$ 140 or Diastolic blood pressure $\geq 90 \mathrm{mmHg}$ ), diabetes mellitus, urinary tract infection, systemic lupus erythematosus and other colagenosis, and previous kidney disease. The 37 patients were compared with 10 healthy volunteers. The protocol of this study was revised and approved by the Ethical Comitee of the Walter Cantidio University Hospital, Federal University of Ceara, Fortaleza, Brazil. Patients were included in the study after signing the informed consent form.

\section{Diagnosis of $A C L$}

Diagnosis of ACL was based on epidemiologic and clinical criteria, Montenegro skin test and identification of parasite in tissue biopsy.

\section{Clinical and laboratory parameters}

At the time of medical consult all symptoms and signals were evaluated, as well as race, age, gender, previous chronic diseases, number of skin lesions, time of disease, use of drugs, body mass index, blood pressure, Montenegro skin test, ACL classification. The following laboratory tests were studied in blood and plasma: urea $\left(\mathrm{P}_{\mathrm{Ur}}\right)$, creatinine $\left(\mathrm{P}_{\mathrm{Cr}}\right), \mathrm{pH}, \quad\left(\mathrm{P}_{\mathrm{osm}}\right)$ osmolality, bicarbonate $\left(\mathrm{BIC}_{\mathrm{s}}\right)$, sodium $\left(\mathrm{P}_{\mathrm{Na}+}\right)$, potassium $\left(\mathrm{P}_{\mathrm{K}_{+}}\right)$, chloride $\left(\mathrm{P}_{\mathrm{Cl}}\right)$, magnesium $\left(\mathrm{P}_{\mathrm{Mg}_{++}}\right)$, calcium $\left(\mathrm{P}_{\mathrm{Ca}++}\right)$, phosphorus $\left(\mathrm{P}_{\mathrm{P}_{-}}\right)$, albumin/globulin, amilase, fast glucose, erythrocyte sedimentation rate (ESR). In urine were studied the following tests: creatinine and urea $\left(\mathrm{U}_{\mathrm{Cr}}\right.$ e $\left.\mathrm{U}_{\mathrm{Ur}_{\mathrm{r}}}\right)$, sodium $\left(\mathrm{U}_{\mathrm{Na}+}\right)$, potassium $\left(\mathrm{U}_{\mathrm{K}+}\right)$, chloride $\left(\mathrm{U}_{\mathrm{Cl}-}\right)$, calcium $\left(\mathrm{U}_{\mathrm{Ca}++}\right)$, phosphorus $\left(\mathrm{U}_{\mathrm{P}-}\right)$, magnesium $\left(\mathrm{U}_{\mathrm{Mg}++}\right)$, microalbuminuria, urinalysis, osmolality $\left(\mathrm{U}_{\mathrm{osm}}\right)$ and $\mathrm{pH}\left(\mathrm{U}_{\mathrm{pH}}\right)$.

\section{Renal function evaluation}

Glomerular filtration rate (GFR) was estimated through the Cockroft \& Gault formula and it was considered abnormal when $\leq 90 \mathrm{ml} / \mathrm{min} / 1,73$ Body Surface Area $\mathrm{m}^{2}$. In an isolated urine sample collected before concentration and acidification tests, pre- and post-glucantime treatment sodium, potassium, chloride, magnesium and microalbuminuria were measured.

All patients underwent food and water deprivation for 12 hours. Fraction excretion of sodium $\left(\mathrm{FE}_{\mathrm{Na}}\right)$, potassium $\left(\mathrm{FE}_{\mathrm{k}}\right)$, calcium $\left(\mathrm{FE}_{\mathrm{Ca}}\right)$, phosphorus $\left(\mathrm{FE}_{\mathrm{P}}\right)$, magnesium $\left(\mathrm{FE}_{\mathrm{Mg}}\right)$ were calculated by standard formula. Microalbuminuria was measured in an isolated urine sample and normalized by urinary creatinine.

Urinary concentration ability was evaluated through the ratio between urinary and serum osmolality $\left(\mathrm{U} / \mathrm{P}_{\mathrm{osm}}\right)$ after 12 hours water deprivation, and urinary osmolality $\left(\mathrm{U}_{\text {osm }}\right)$ was measured before and 4 hours after administration of intranasal DDAVP ${ }^{\circledR}$ (desmopressin acetate $20 \mathrm{mcg} / \mathrm{kg}-\mathrm{T}_{0}$ and $\mathrm{T}_{4}$ ). Urinary acidification was evaluated by the urinary $\mathrm{pH}$ before and after administration of oral $\mathrm{CaCl}_{2} 2 \mathrm{mEq} / \mathrm{kg}\left(\mathrm{T}_{0}\right.$ and $\left.\mathrm{T}_{4}\right)$. Acidification defect was determined by the inability in decreasing $\mathrm{U}_{\mathrm{pH}}$ for less than 5.50 .

All patients underwent standard treatment with antimonial (Glucantime ${ }^{\circledR}$ ) in the dose of $20 \mathrm{mg} / \mathrm{kg} /$ day for 20 days. All tests were done before treatment and 4 weeks after the beginning of the treatment.

\section{Groups definition}

Pre-glucantime group - Tests performed before the beginning of treatment.

Post-glucantime group - Tests performed 4 weeks after the beginning of the treatment.

\section{Analytical methods}

Urea: Determined by colorimetric uricase method (Labtest $\left.{ }^{\circledR}\right)$. The results were expressed in $\mathrm{mg} / \mathrm{dl}$. Serum and urinary creatinine: Determined by colorimetric methods, picric acid, Taussky and Bonsness (Labtest ${ }^{\circledR}$ ). The results were expressed in $\mathrm{mg} / \mathrm{dl}$. Serum and urinary Sodium and potassium $\left(\mathrm{P}_{\mathrm{Na}+}\right.$ e $\left.\mathrm{P}_{\mathrm{K}+}\right)$ : Determined by photometry technique with spectrophotometry, model B462 MICRONAL (Instrumentation Laboratory, Inc. USA). The results were expressed in $\mathrm{mEq} / \mathrm{L}$. Albumin: Determined by bromocresol reaction (Labtest ${ }^{\circledR}$ ). The results were expressed in g/dl. Globulin: Determined by bromocresol reaction (Labtest ${ }^{\circledR}$ ). The results were expressed in g/dl. Glucose: Determined by colorimetric glucose oxidase method $\left(\right.$ Labtest $\left.{ }^{\circledR}\right)$. The results were expressed in $\mathrm{mg} / \mathrm{dl}$. Alkaline phosphatase: Determined by phosphatase kinetic method, Bowers and Mc Comb modified (Labtest ${ }^{\circledR}$ ). The results were expressed in U/L. Amilase: Determined by colorimetric Caraway modified method. 
Results expressed in $\mathrm{U} / \mathrm{dl}$. pH, bicarbonate $\left(\mathrm{HCO}^{-}\right)$: were determined through "Blood gas analyser" machine (chiron diagnostic $238-$ Bayer $^{\mathrm{B}}$ ). The results were expressed in $\mathrm{mEq} / \mathrm{L}$ for bicarbonate. Urinary $\mathrm{pH}\left(\mathrm{U}_{\mathrm{pH}}\right)$ : measured by pHmetro Digital pG1000, model GEHAKALT. Urinary osmolarity: Determined by the technique pressure steam in osmometer model $5100 \mathrm{C}$ (Wescor Inc., USA). The results were expressed in $\mathrm{mOsm} / \mathrm{Kg}$. $\mathrm{H}_{2} \mathrm{O}$. Microalbuminuria: measured through immunoturbidimetry methods, using Tina-quant ${ }^{\circledR}$ kit (Roche) and the results were expressed in $\mathrm{mcg} / \mathrm{g}$ creatinine.

\section{Statistical analysis}

All quantitative data are expressed as mean \pm SEM. Differences between two parameters were analyzed either by paired Student $t$ test or by nonparametric methods (Wilcoxon test and Mann-Whitney test). Chi-square test was used to analyze categoricalvariables. Values of $\mathrm{P}<0.05$ were considered statistically significant.

\section{Results}

Of the 59 patients enrolled in the study with previously diagnosed of ACL on the basis of epidemiological, clinical, biochemical, and histopathological findings 22 were excluded: eight for testing negative on a new histopathological exam; nine for being under 15 years of age or over 60 years of age; two for subsequently declining to participate in the study; one for having hypertension; one for having diabetes mellitus; and one for having used an antimonial (meglumine antimoniate) within the last 30 days. Therefore, the study group included $37 \mathrm{ACL}$ patients who agree to participate. The mean age was $35.6 \pm 12$ years and $19(51.4 \%)$ were male. Clinical and demographic data were similar between ACL patients and controls (Table 1).

Montenegro skin test was positive in $59.5 \%$ of cases. All patients have ACL in its isolated cutaneous type, 27 had a solitary skin lesion, 7 had 2-4 lesions and 3 had more than 4 lesions. The mean time of disease was $28.5 \pm 20.6$ days (range $7-90$ days).

The laboratory evaluation, before and after treatment with pentavalent antimonial, is shown in Table 2. It was observed only a mild decrease in hemoglobin posttreatment. In biochemical analysis it was noted an increase in aminotransferases $(\mathrm{p}<0.05)$ after treatment. No one patient presented increase in serum amylase with treatment.

There was no significant glomerular filtration abnormality before and after treatment $(109.6 \pm 32$ vs. $109.6 \pm$ $\left.28 \mathrm{ml} / \mathrm{min} / 1.73 \mathrm{~m}^{2}, P=0.694\right)$. Microalbuminuria was $23.6 \pm 26 \mathrm{mg} / \mathrm{g}$ creatinine, before treatment, and $14.6 \pm 18.9 \mathrm{mg} / \mathrm{g}$ creatinine after treatment $(\mathrm{p}=0.02)$. Urinary concentrating defect, based on U/Posm $(<2,8)$, was observed in 27 patients before treatment and in 30
Table 1 Clinical and demographic data of patients with ACL compared with healthy subjects

\begin{tabular}{|c|c|c|c|}
\hline Characteristics & $\begin{array}{c}\mathrm{ACL} \\
(n=37)\end{array}$ & $\begin{array}{l}\text { Control } \\
(n=10)\end{array}$ & $P$ \\
\hline Age (years) & $35.6 \pm 12$ & $32.3 \pm 11.7$ & 0.442 \\
\hline \multicolumn{4}{|l|}{ Gender } \\
\hline Male & 19 (51.4\%) & $6(60 \%)$ & 0.73 \\
\hline Female & $18(48.6 \%)$ & $4(40 \%)$ & \\
\hline Time of disease (days) & $28.5 \pm 20.6$ & - & - \\
\hline Montenegro skin test $(+/-)$ & $22 / 37$ & - & - \\
\hline \multicolumn{4}{|l|}{ Number of skin lesions } \\
\hline 1 & $27(72.9 \%)$ & - & - \\
\hline 2 to 4 & 7 (18.9\%) & - & - \\
\hline$>4$ & $3(8.1 \%)$ & & \\
\hline Systolic blood pressure, $\mathrm{mmHg}$ & $122 \pm 10$ & $117 \pm 9.5$ & 0.221 \\
\hline Diastolic blood pressure, $\mathrm{mmHg}$ & $80 \pm 4.7$ & $75 \pm 8.5$ & 0.079 \\
\hline
\end{tabular}

Data expressed as mean \pm standard deviation or \%. Student $t$ test.

after treatment $(77 \%$ vs. $88 \%, p=0,344)$, with no significant difference between pre and post-treatment $(2.2 \pm$ 0.7 vs. $1.9 \pm 0.75, P=0.718$ ) (Table 3 ).

Urinary acidification defect, defined as the inability to reduce urinary $\mathrm{pH}$ to $<5.5$ after $\mathrm{CaCl}_{2}$ administration, was observed in 15 patients before treatment and in only 6 after treatment ( $40 \%$ vs $16 \%, p=0.012)$, with significant difference when comparing the $\mathrm{pH}$ values before and after treatment $(5.50 \pm 0.64$ vs. $5.19 \pm 0.60$, $P=0.0066)$. After treatment, 18 among 36 patients $(50 \%)$ presented $\mathrm{P}_{\mathrm{HCO}^{-}}-<21 \mathrm{mEq} / \mathrm{L}$, and $\mathrm{pH}<7.35$ was seen

Table 2 Laboratory data of 37 patients with ACL before and after specific treatment

\begin{tabular}{|c|c|c|c|}
\hline & Pre-treatment & Post-treatment & $P$ \\
\hline Hematocrit (\%) & $42.6 \pm 4.1$ & $40.5 \pm 4.2$ & 0.0052 \\
\hline Hemoglobin (g/\%) & $13.9 \pm 1.2$ & $13.3 \pm 1.5$ & 0.019 \\
\hline White blood count $\left(/ \mathrm{mm}^{3}\right)$ & $6.359 \pm 1918$ & $6.035 \pm 1513$ & 0.269 \\
\hline Platelets $\left(/ \mathrm{mm}^{3}\right)$ & $275.351 \pm 66.259$ & $292.702 \pm 60.570$ & 0.074 \\
\hline Arterial pH & $7.35 \pm 0.1$ & $7.35 \pm 0.1$ & 0.634 \\
\hline Fasting glucose (mg/dl) & $80 \pm 15$ & $80 \pm 17$ & 0.915 \\
\hline Amylase (U/dl) & $143 \pm 48$ & $148 \pm 62$ & 0.666 \\
\hline Total Bilirubin (mg/dl) & $0.5 \pm 0.27$ & $0.6 \pm 0.23$ & 0.810 \\
\hline Alkaline Phosphatase (U/L) & $93 \pm 33$ & $107 \pm 52$ & 0.08 \\
\hline Albumin (g/dl) & $4 \pm 0.6$ & $4 \pm 0.6$ & 0.696 \\
\hline Globulin (g/dl) & $3.3 \pm 0.86$ & $3.3 \pm 0.7$ & 0.135 \\
\hline AST (g/dl) & $34 \pm 15$ & $46 \pm 36$ & 0.034 \\
\hline ALT (U/L) & $28 \pm 19$ & $42 \pm 33$ & 0.023 \\
\hline ESR (mm/h) & $30 \pm 21$ & $26 \pm 18$ & 0.198 \\
\hline
\end{tabular}

Significant $P<0.05$. AST: aspartate aminotransferase; ALT: alanine aminotransferase; ESR: erythrocyte sedimentation rate. Data expressed as mean \pm standard deviation or $\%$. T test and Wilcoxon test. 
Table 3 Glomerular and tubular function of 37 patients with ACL before and after specific treatment

\begin{tabular}{|c|c|c|c|}
\hline & $\begin{array}{l}\text { Pre- } \\
\text { glucantime } \\
(\mathrm{N}=37)\end{array}$ & $\begin{array}{l}\text { Post- } \\
\text { glucantime } \\
(\mathrm{N}=37)\end{array}$ & $\begin{array}{l}\text { Control } \\
(\mathrm{N}=10)\end{array}$ \\
\hline$P_{\text {creat }},(\mathbf{m g} / \mathrm{dl})$ & $0.81 \pm 0.16$ & $0.81 \pm 0.15$ & $0.85 \pm 0.18$ \\
\hline $\mathrm{CrCl}\left(\mathrm{ml} / \mathrm{min} / 1.73 \mathrm{~m}^{2}\right)$ & $109.6 \pm 31.5$ & $108.4 \pm 28.5$ & $116.4 \pm 22.7$ \\
\hline U/P osm T4 & $2.19 \pm 0.73$ & $1.95 \pm 0.73$ & $3.47 \pm 0.33$ \\
\hline $\mathrm{U}_{\mathrm{pH}} \mathrm{T4}$ & $5.45 \pm 0.64$ & $5.19 \pm 0.60^{*}$ & $4.82 \pm 0.20$ \# \\
\hline $\mathrm{U}_{\mathrm{osm}} \mathrm{T4}$ & $618 \pm 202$ & $552 \pm 210$ & $965 \pm 81^{\#}$ \\
\hline FENa, (\%) & $1.15 \pm 0.74$ & $1.35 \pm 1.51^{* *}$ & $0.73 \pm 0.39$ \\
\hline FEk, (\%) & $10 \pm 6.6$ & $10.1 \pm 7.6$ & $7.50 \pm 2.8^{\#}$ \\
\hline FECa (\%) & $1.07 \pm 0.72$ & $1.32 \pm 1.01$ & $0.62 \pm 0.34^{\#}$ \\
\hline FEPO4 (\%) & $10.9 \pm 9.98$ & $10.9 \pm 15.7$ & $9.10 \pm 6.4$ \\
\hline FEMg (\%) & $1.81 \pm 1.70$ & $1.90 \pm 1.44$ & $0.90 \pm 0.40^{\#}$ \\
\hline $\begin{array}{l}\text { Microalbuminuria } \\
\text { (mg/g creatinine) }\end{array}$ & $23.6 \pm 26^{* * *}$ & $14.6 \pm 18.9$ & $6.12 \pm 4.06$ \\
\hline
\end{tabular}

* Pre vs. Post-glucantime, $\mathrm{p}=0.0066$; \# control vs. Pre and post-glucantime, $p<0.05$; **Post-glucantime vs. control, $p=0.048$; ***pre vs. post-glucantime, $p=0.025$. DATA: MEAN \pm SD. Student t test, Mann-Whitney.

$P_{\text {crea }}$ - SerumCreatinine.

$\mathrm{CrCl}$ - Creatinine clearance.

$\mathrm{U} / \mathrm{P}_{\mathrm{osm}}$ - Urinary and serum osmolarity ratio.

$\mathrm{U}_{\mathrm{pH}}$ em T4 - Urinary pH in T4.

$\mathrm{U}_{\text {osm }} \mathrm{T} 4$ - Urinary osmolality in T4.

FE: fraction excretion.

in $42 \%$ cases. Regarding excretion fractions (FENa, FEk, FECa, FEP and FEMg) there was no significant differences in the values before and after treatment (Table 4). $\mathrm{FE}_{\mathrm{Na+}}>2 \%$ was found in 4 patients $(10.8 \%), \mathrm{FE}_{\mathrm{k}+}>10 \%$ in 11 patients $(29.7 \%), \mathrm{FE}_{\mathrm{Ca}++}>3 \%$ in 2 patients $(5.4 \%)$,

Table 4 Prevalence of renal dysfunction in 37 patients with ACL before and after specific treatment

\begin{tabular}{|c|c|c|c|}
\hline & $\begin{array}{l}\text { Pre- } \\
\text { treatment }\end{array}$ & $\begin{array}{l}\text { Post- } \\
\text { treatment }\end{array}$ & $\mathbf{P}$ \\
\hline$P_{\text {creat }}>1.2 \mathrm{mg} / \mathrm{dl}$ & - & - & - \\
\hline $\mathrm{CrCl}<90 \mathrm{ml} / \mathrm{min} / 1.73 \mathrm{~m}^{2}$ & $11(30 \%)$ & $12(32 \%)$ & 1.000 \\
\hline Microalbuminuria $>\mathbf{3 0} \mathbf{~ m g} / \mathrm{g}$ creat & $12(39 \%)$ & $3(10 \%)$ & 0.004 \\
\hline $\mathrm{U}_{\mathrm{osm}} \mathrm{T} 4<700 \mathrm{mmOsm} / \mathrm{kg} \mathrm{H} \mathrm{H}_{2} \mathrm{O}$ & $21(62 \%)$ & $24(71 \%)$ & 0.508 \\
\hline U/P osm $T 4<2.8$ & $26(77 \%)$ & $30(88 \%)$ & 0.344 \\
\hline $\mathrm{U}_{\mathrm{pH}} \mathrm{T4}>5.5$ & 15 (40\%) & $6(16 \%)$ & 0.012 \\
\hline$E F_{\mathrm{Na}+}>2 \%$ & $5(14 \%)$ & $4(11 \%)$ & 1.000 \\
\hline$E_{k_{+}}>10 \%$ & $12(32 \%)$ & $11(30 \%)$ & 1.000 \\
\hline $\mathrm{EF}_{\mathrm{Ca}++}>\mathbf{3} \%$ & $2(5 \%)$ & $2(5 \%)$ & 1.000 \\
\hline$E_{\text {PO4- }}>10 \%$ & $17(46 \%)$ & $10(27 \%)$ & 0.143 \\
\hline $\mathrm{EF}_{\mathrm{Mg++}}>6 \%$ & $1(2.7 \%)$ & $1(2.7 \%)$ & 1.000 \\
\hline \multicolumn{4}{|c|}{$\begin{array}{l}\mathrm{P}_{\text {crea }} \text { - plasma creatinine; } \mathrm{Cr}_{\mathrm{Cl}}-\text { creatinine clearance; } \mathrm{U} / \mathrm{P}_{\mathrm{osm}}-\text { urine and } \\
\text { plasma osmolarity ratio; } \mathrm{U}_{\mathrm{pH}} \mathrm{T} 4 \text { - urine } \mathrm{pH} \text { in } \mathrm{T} 4 \text { (4 hours after } \mathrm{CaCl}_{2} \\
\text { administration); } \mathrm{U}_{\mathrm{osm}} \mathrm{T} 4 \text { - urine osmolariry in } \mathrm{T} 4 \text { (4 hours after } \mathrm{DDAVP} \\
\text { administration); } \mathrm{EF}_{\mathrm{Na}} \text { - Sodium excretion fraction; } \mathrm{EF}_{\mathrm{K}}-\text { Potassium excretion } \\
\text { fraction; } \mathrm{EF}_{\mathrm{Ca}}-\text { Calcium excretion fraction; } \mathrm{EF}_{\mathrm{Mg}}-\text { Magnesium excretion } \\
\text { fraction. Data expressed as percentage (\%). }\end{array}$} \\
\hline
\end{tabular}

$\mathrm{FE}_{\mathrm{PO} 4^{-}}>10 \%$ in 10 patients $(29 \%)$ and $\mathrm{FE}_{\mathrm{Mg++}}>6 \%$ in only 1 patient $(2.7 \%)$.

None of the patients presented severe adverse reactions to the pentavalent antimonial. Among the 37 studied cases, 5 (13.5\%) presented low degree fever, myalgia and asthenia, and one patient had arthralgia and headache.

\section{Discussion}

The results of the present study evidence the occurrence of asymptomatic tubular dysfunction probably induced by $\mathrm{ACL}$ and that partially improved after specific treatment.

All patients studied had ulcerated lesions. They were in very early stages of the disease, however they presented systemic inflammatory reactions, such as fever, arthralgias and myalgias, which have been previously reported [17]. This can lead to humoral activation, which can explain the finding of renal tubular dysfunction.

In the present study, the number of patients with $\mathrm{Cl}_{\mathrm{Cr}}<90 \mathrm{ml} / \mathrm{min} / 1.73 \mathrm{~m}^{2}$ did not present significant difference before and after treatment with pentavalent antimonial (11 among 37 before treatment and 12 among 37 after treatment). Previous reports on the renal involvement in ACL have linked renal abnormalities to the use of these drugs, as acute kidney injury by tubulointerstitial nephritis or reaction Jarish-Herxheimer like, which is not in accordance to our findings [12,15].

Renal dysfunction in visceral leishmaniasis (kala-azar) has been described [7-10,18]. Lima Verde et al [14] in a study with 50 patients with kala-azar found GFR $<80 \mathrm{ml} / \mathrm{min} / 1.73 \mathrm{~m}^{2}$ in 14 cases (28\%). In another study, including 224 patients with kala-azar, acute kidney injury was found in 76 cases $(33.9 \%)$ and this complication was associated with increased mortality [10]. In a recent study by Daher et al [19], renal tubular dysfunction in kala-azar significantly improved after treatment with pentavalent antimonial. After specific treatment, all patients in the present study still remained with urinary concentrating and two-thirds improved previous acidification defects, suggesting that the tubular damage can be irreversible.

In our study microalbuminuria higher than $30 \mathrm{mg} / \mathrm{g}$ was found in $35 \%$ of patients before treatment and in only $8 \%$ after treatment, suggesting that glomerular lesion in ACL could have been caused by the parasitic disease per se, but without GFR reduction. In a study with 11 patients with kala-azar, 8 presented increased microalbuminuria $(81.8 \%$ ), which is higher than that found in ACL [7]. Elnojomi et al [20] detected abnormal microalbuminuria in 35 out of $88(40 \%)$ patients with kala-azar, with no glomerular dysfunction. Microalbuminuria can also be found in other infectious diseases that affect the skin and nerves, such as leprosy. Oliveira et al [21] identified microalbuminuria in 4 out of 59 patients with multibacillary leprosy (8.5\%). A higher prevalence 
of microalbuminuria was found in another study involving leprosy patients. Kirsztajn et al [22]. identified microalbuminuria higher than $20 \mathrm{mg} / \mathrm{l}$ in $15.8 \%$ of 96 patients with leprosy. In the present study we observed a decrease in microalbuminuria after treatment, which suggests that ACL per se can lead to increased urinary albumin loss. However microalbuminuria is not yet a well defined marker of glomerular dysfunction in infectious diseases.

In the present study, the urinary concentrating ability was evaluated by the ratio $\mathrm{U} / \mathrm{P}_{\text {osm }}$ and $\mathrm{U}_{\text {osm }}$, measured after $12 \mathrm{~h}$ water deprivation and fasting, which was sensitized by the administration of DDAVP. Urinary concentration deficit was found in 27 cases (77\%) before treatment and in $31(88 \%)$ after treatment $(\mathrm{p}=0.344)$. There was also no significant difference in the values of $U_{\text {osm }}$ after the administration of DDAVP before and after treatment $(p=0.508)$. Based on these findings we can suggest that ACL per se can cause urinary concentrating deficit. The specific treatment did not improve this abnormality, but do not allow a worsening in the tubular lesion.

In a study involving 11 patients with ACL treated with pentavalent antimonial, $40 \mathrm{mg} / \mathrm{kg}$ for 30 days, the persisting urinary concentrating deficit was observed in 8 cases (72.7\%) [23]. Veiga et al [24], reported 5 cases of ACL treated with pentavalent antimonial in conventional doses, but with a longer duration, which developed urinary concentrating inability. Lima Verde et al [14], found $68 \%$ of urinary concentrating capacity defect in patients with kala-azar before pentavalent antimonial therapy. The persistence of this abnormality can be a consequence of ACL itself, which can cause a severe tubular damage. Further investigations, with a longer period of observation after ACL treatment, would be important to establish the long-term outcomes regarding this complication. Maybe urinary concentrating ability can be restored with time in this group of patients.

In the present study urinary acidification defect was found in $40 \%$ of the patients before treatment and in $16 \%$ after treatment, which suggests an important improvement in acidification ability after specific treatment for ACL. Urinary acidification deficit is less common than concentration deficit. In a study with patients with kala-azar, urinary acidification defect was found in $64 \%$ of cases after specific treatment [14].

\section{Conclusions}

Renal abnormalities detected in ACL improve partially after specific treatment, especially microalbuminuria and urinary acidification. The persistent urinary concentranting deficit may be related to a permanent damage induced by ACL or maybe an overlap effect of the treatment and the disease. Further studies are required to better understand the mechanisms involved in tubular dysfunction caused by ACL and by the treatment.

\section{Competing interests}

The authors declare that they have no competing interests.

\section{Authors' contributions}

RAO and CGL carried the patients'evaluation and collection of biological samples for laboratory tests and drafted the manuscript. TRS and AMCM carried out the laboratory tests. RMSM participated in the design of the study and performed the statistical analysis. RAO, ACS, LCA, GBSJ, ABL and EFD conceived the study, and participated in its design and coordination and helped to draft the manuscript. All authors read and approved the final manuscript.

\section{Acknowledgements}

This research was supported by the Brazilian National Council for Scientific and Technological Development (CNPq). The desmopressin acetate was provided by Ferring of Brazil.

\section{Author details}

'Department of Internal Medicine, School of Medicine, Federal University of Ceará, Campus Cariri, Rua Divino Salvador, 284, Centro, Barbalha, Ceará, Brazil CEP-63180-000. '2Department of Statistics, Sciences Center, Federal University of Ceará, Fortaleza, Ceará, Brazil. ${ }^{3}$ School of Pharmacy, Federal University of Ceará, Fortaleza, Ceará, Brazil. ${ }^{4}$ Division of Nephrology, School of Medicine, University of São Paulo, São Paulo, Brazil. ${ }^{5}$ Department of Internal Medicine, School of Medicine, Federal University of Ceará, Campus Fortaleza, Fortaleza, Ceará, Brazil. ${ }^{6}$ School of Medicine, Health Sciences Center, University of Fortaleza, Fortaleza, Ceará, Brazil. "BBrazilian National Research Council (CNPq), São Paulo, Brazil.

Received: 24 November 2011 Accepted: 14 June 2012 Published: 20 June 2012

\section{References}

1. Goto H, Lindoso JAL: Current diagnosis and treatment of cutaneous and mucocutaneous leishmaniasis. Expert Rev Anti Infect Ther 2010, 8:419-433.

2. Barral B, Pedral-Sampaio D, Grimaldi G Jr, Momen H, Mc Mahon-Pratt D, Ribeiro de Jesus A, Almeida R, Badaró R, Barral-Neto M, Carvalho EM, Johnson WD Jr: Leishmaniasis in Bahia, Brazil: evidence that Leishmania amazonensis produces a wide spectrum of clinical disease. Am J Trop Med Hyg 1991, 44:536-546.

3. Grimaldi G Jr, Mc-Mahon-Pratt D, Sun T: Leishmaniasis and its etiologic agents in the New World: an overview. Prog Clin Parasitol 1991, 2:73-118.

4. Gontijo B, Carvalho MLR: Leishmaniose Tegumentar Americana. Rev Soc Bras Med Trop 2003, 36:71-80.

5. Desjeux P: Leishmaniasis: current situation and new perspectives. Comp Immunol Microbiol Infect Dis 2004, 27:305-318.

6. Roberts LJ, Handeman E, Foote SJ: Leishmaniasis. Br Med J 2000, 321:801-804.

7. Salgado-Filho N, Ferreira TM, Costa JM: Envolvimento da função renal em pacientes com leishmaniose visceral (calazar). Rev Soc Bras Med Trop 2003, 36:217-221.

8. Chaigne V, Knefati Y, Lafarge R, Bronner J, MC Gregor B, Fouque B, Sabatier $J C$ : A patient with visceral leishmaniasis and acute renal failure in necrotizing glomerulonephritis. Nephrologie 2004, 25:179-183.

9. Duvic C, Nedelec G, Debord T, Herody M, Didelot F: Important parasitic nephropathies: update from recent literature. Nephrologie 1999, 20:65-74.

10. Oliveira MJC, Silva Júnior GB, Abreu KLS, Rocha NA, Garcia AW, Franco LFLG, Mota RMS, Libório AB, Daher EF: Risk factors for acute kidney injury in visceral leishmaniasis. Am J Trop Med Hyg 2010, 83:449-453.

11. Councilman WT: Acute interstitial nephritis. J Experiment Med 1988, 3:393-420.

12. Cucé $L C$, Belda J, Dias W: Nephrotoxicyty to Glucantime ${ }^{\circledR}$ in the treatment of leishmaniasis. Rev Inst Med Trop S Paulo 1990, 32:249-251.

13. Duarte MIS, Silva MRR, Gotto H, Nicodemo EL, Amato-Neto V: Interstitial nephritis in human kala-azar. Trans R Soc Trop Med Hyg 1983, 77:531-537.

14. Lima Verde EM, Lima Verde FAA, Lima Verde FA, Silva Júnior GB, Daher EF: Evaluation of renal function in human visceral leishmaniasis (kala-azar): a prospective study on 50 patients from Brazil. J Nephrol 2007, 20:432-438. 
15. Rodrigues MLO, Costa RS, Souza CS, Fossi NT, Roselino AMF: Nephrotoxicity attributed to meglumine antimoniate (Glucantime) in the treatment of generalized cutaneous leishmaniasis. Rev Inst Med Trop S Paulo 1999, 41:33-37.

16. Oliveira RA, Diniz LFB, Teotonio LO, et al: Renal tubular dysfunction in patients with American cutaneous leishmaniasis. Kidney Int 2011, 80:1099-1106.

17. Abadir A, Patel A, Haider S: Systemic therapy of new world cutaneous leishmaniasis: a case report and review article. Can J Infect Dis Med Microbiol 2010, 21:e79-e83.

18. Dutra $M$, Martinelli $R$, de Carvalho EM, et al: Renal involvement in visceral leishmaniasis. Am J Kidney Dis 1985, 6:22-27.

19. Daher EF, Rocha NA, Oliveira MJ, Franco LF, Oliveira JL, Silva Junior GB, Abreu KL, Henn GA, Martins AM, Libório AB: Renal function improvement with pentavalent antimonial agents in patients with visceral leishmaniasis. Am J Nephrol 2011, 33:332-336.

20. Elnojomi N, Musa AM, Younis BM, Elfaki M, EL-Hassan AM, Khalil E: Surrogate markers of subtle renal injury in patients with visceral leishmaniasis. Saudi J Kidney Dis Transp/ 2010, 21:872-875.

21. Oliveira RA, Silva GB Jr, Souza CJ, et al: Evaluation of renal function in leprosy: a study of 59 consecutive patients. Nephrol Dial Transplant 2008, 23:256-262.

22. Kirsztajn GM, Nishida SK, Silva MS, Ajzen H, Pereira AB: Renal abnormalities in Leprosy. Nephron 1993, 65:381-384.

23. Sampaio RNR, Paula CDR, Sampaio JHD, Furtado RS, Leal PP, Rosa TT, Rodrigues MR, Veiga JPR: Avaliação da tolerância e nefrotoxicidade do antimonial pentavalente administrado na dose de $40 \mathrm{mg} \mathrm{Sb} / \mathrm{kg} /$ dia por 30 dias na forma cutânea-mucosa de leishmaniose. Rev Soc Bras Med Trop 1997, 30:457-467.

24. Veiga JPR, Khanan R, Rosa TT, Junqueira LF Jr, Brant PC, Raick AN, Friedman $H$, Marsden PD: Pentavalent antimonial nephrotoxicity in the rat. Rev Inst Med Trop S Paulo 1990, 32:304-309.

doi:10.1186/1471-2369-13-44

Cite this article as: Oliveira et al:: Renal function evaluation in patients with American Cutaneous Leishmaniasis after specific treatment with pentavalent antimonial. BMC Nephrology 2012 13:44.

\section{Submit your next manuscript to BioMed Central and take full advantage of:}

- Convenient online submission

- Thorough peer review

- No space constraints or color figure charges

- Immediate publication on acceptance

- Inclusion in PubMed, CAS, Scopus and Google Scholar

- Research which is freely available for redistribution 